\begin{tabular}{|c|c|}
\hline 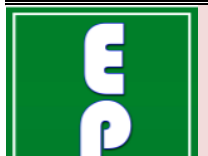 & $\begin{array}{c}\text { International Journal of Current Research } \\
\text { and Academic Review }\end{array}$ \\
\hline $\begin{array}{l}\text { XCELLENT } \\
\text { UBLISHERS } \\
\end{array}$ & 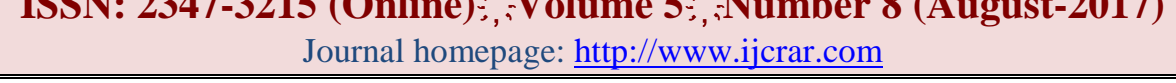 \\
\hline
\end{tabular}

doi: https://doi.org/10.20546/ijcrar.2017.508.016

\title{
Assessing the Impact of Agricultural Mechanization Centers on Agriculture Production and Rural Livelihoods in the Upper East Region, Ghana
}

\author{
Maurice Mustapha. Braimah ${ }^{1^{*}}$, Bright Buzong Yintii ${ }^{2}$ and Avomah Oscar Mac Akampirige \\ ${ }^{I}$ School of Engineering, Department of Agricultural Engineering, Bolgatanga Polytechnic, Ghana \\ ${ }^{2}$ School of Applied Science \& Arts, Department of Ecological Agriculture, Bolgatanga Polytechnic, Ghana \\ ${ }^{3}$ School of Applied Science \& Arts, Department Of Liberal Studies, Bolgatanga Polytechnic, Ghana \\ *Corresponding author
}

\begin{abstract}
The impact of mechanization centers on agricultural production in the Upper East Region. Agricultural mechanization which encapsulates the use of non-human power sources to carry out a range of agricultural operations including ploughing, harvesting, shelling and planting, has over the last two decades been on the rise among local farmers in northern savannah with much of this demand concentrated on land preparation. In all, Ten (10) Farm Mechanization Centers were purposively sampled across all Thirteen (13) Districts in the Upper East Region. In addition, One Hundred (100) smallholder farmers were also selected for the sample frame. In order to meet the objective of ensuring a uniform spatial coverage of all the selected Districts, Bolgatanga, Navrongo and Fumbisi were sampled from across the Upper East Region. The study shows a positive relationship between tractor use and farm size expansion among smallholder farmers in the Upper East Region of Ghana. Findings show that farm size expansion over the one-decade occurred among majority of respondent smallholder farmers irrespective of landholding size. Notwithstanding the contributory role of other factors that enhanced their ability to expand, especially the availability of demand for farm produce, all respondent farmers noted that tractor use was the primary catalyst that aided the expansion of their farms. On the challenges faced by the Tractor operators, the result indicates that bad road network from the rural to the urban communities served as the major challenge as faced by tractor operators. This makes it difficult for them to move into the farm lands any time there is a heavy downpour of rain. The cost associated to the operations of a tractor such as cost of production, fuel and maintenance of the tractor were also concerns raised by the respondents. It is therefore, recommended that, mechanization centers be made available by Government to all smallholder farmers. In addition to that, strong extension services, Agriculture infrastructure development and a solid Agro-based industries which have direct linkage to smallholder farms be fully implemented.
\end{abstract}

\section{Article Info}

Accepted: 30 July 2017

Available Online: 20 August 2017

\section{Keywords}

Impact,

Agriculture,

Ploughing,

Farm 


\section{Introduction}

Agriculture is a major contributor in rural poverty reduction and improvement in livelihood in Ghana. Majority of rural community members depend largely on small-scale farming as the major livelihood strategy and little or no alternative livelihood source. The National Development Planning Commission (Asuming Brempong et al., (2005) mentioned that about 3,225,910 representing $81 \%$ of Ghanaiansfarming population are smallholder farmers whose survival depends on farming. Their major livelihood asset base is land which is said to be small ranging from 4 hectares in the forest ecological zone to 1.2 hectares in the interior savannah. The Upper East Region, for instance, has an average landholding size of 1.2 hectares (Andah et al., 2003). This small land holding size has implication on the level of production and attempt needs to be done to increase productivity as the area of cultivation is diminishing in quantity and quality in food crops. This calls for the need to improve on agricultural technology in rural Ghana. As a result of the above, mechanization centers to support agricultural transformation and hence rural poverty reduction and improvement in livelihoods were developed by government and relevant actors.

In order to enhance the development of agriculture, attempts have been made through the development and implementation of policies which include: the Ghana Poverty Reduction Strategy (GPRSI) and the Growth and Poverty Reduction Strategy (GPRSII), The Medium Term Agricultural Development Program (MTADP), the Accelerated Agricultural Growth and Development Strategy (AAGDS), and the Food and Agricultural Sector Development Policy (FASDEP I and II). All the mentioned documents have their focus on the transition from rural subsistence farming to mechanized commercially attractive, viable and dynamic agribusiness. FASDEP is based on the realization that Ghana cannot achieve its planned economic growth and poverty reduction without significant improvement on the performance of the agricultural sector (FASDEP, 2002).

Even though, the investment in the mechanization technology in Ghana has faced some challenges by developing mechanization centers. This may have affected the lives of beneficiary communities, the local economy and national development as a whole. It is worth to evaluate the contributions or otherwise adverse effects of the mechanization centers and other facilities related to farm mechanization among communities and smallholder farming households.
It contributed the highest proportion to gross domestic product (GDP) since independence but has of recent being overtaking by the services sector which contributed up to $32.8 \%$ against $32.4 \%$ of agricultural GDP contribution in 2010 (MOFEP 2011). Weather conditions, low technology adoption rate, reasons for the poor performance of the agricultural sector in Ghana. Poverty is the inability to command sufficient resources to satisfy basic needs (Todaro, 2003). This means the inability of people to meet basic needs such as food, health, education, shelter and to participate in decision making that affect them. To address the above issue several efforts have been made during the years past and now to address the situation. All these efforts are geared towards improving on the livelihoods of peasant farmers but have met a lot of challenges. Some of these challenges are the poor state of infrastructural facilities in upper east region is also a factor hindering agricultural mechanization.

This case study tried to investigate investment in mechanization centers and other farm technology has affected livelihood development among rural communities in the Upper East Region, with its focus on poverty reduction in relation to change in income levels, food security, employment generation, and asset building. It also tried to link the development of mechanization centers with agricultural production to reduce poverty and how other infrastructural development alongside mechanization centers could promote agricultural development.

The broad objective of this study is to show the extent of benefits or non-benefits derived from the impact of mechanization centers on agricultural production. The specific objectives for this study are to: To determine the number of mechanizationcenters in the Upper East Region; Examine the support mechanizationcenters give in the rural livelihood development in the Upper East Region; Find out how agricultural mechanizationcenters affect the livelihood of the rural household in the Upper East Region and Assess the levels of utilization of agricultural machinery in crop yield in the Upper East Region.

\section{Limitation}

A study of this nature would have required an exhaustive enquiry in all mechanization facilities, both small-scale and major schemes in the Upper East Region sector of the country. However, time and resource constraint would not permit one to do that, hence the concentration 
on the Mechanization centers in Tono, Vea and Fumbisi Valleys, as a case study. It was difficult to obtain information of the farmers, because of their experience with some NGOs and research institutions, paying for time spent with them during data collection this led to several calls that yielded increased cost on travelling. The sample size in relation to the population of farmers operating on the project. In addition, the study only covered three Districts on mechanization centers for farmers. This does not however derail the significance of the study, as it seeks to uncover situations on the ground, with the hope that the findings could be applicable in other Regions of the country.

\section{Materials and Methods}

\section{Description of the Study Area}

The study region Upper East Region (Fig 3.1) is located on the North-East corner of Ghana between latitudes $10^{\circ}$ $30^{\prime}$ to $11^{\circ}$ North and longitudes $0^{\circ}$ to $1^{\circ} 30^{\prime}$ West within the White Volta River Basin (GSS, 2012). The Upper East Region has two international boundaries with the republics of Burkina Faso to the North and Togo to the East. The other boundaries are Northern Region and Upper West Region to the South and West respectively (GSS, 2012).The movement of the Intertropical Convergence Zone (ITCZ), between the north and south tropics, brings about dry and wet periods, the two main climatic seasons in Ghana (McSweeney et al., 2012). Dry periods are experienced when the 'Harmattan' wind blows north-easterly across the northern part of Ghana (Gordon, 2009).

The Upper East Region lies within the Guinea Savannah and Sudan Savannah climatic zones and has a unimodal rainfall pattern. The natural vegetation is characterized by short scattered drought-resistant trees and grass that gets burnt by bushfire or scorched by the sun during the long dry season (Tetteh, 2007). About 85 percent of the entire region falls within the White Volta basin, the Red and the Sissile River. The Kulpawn River which has its catchment to the south-west of the region is joined by the Sissile just before its confluence with the White Volta. Besides these, there are other smaller water bodies that give the region a great potential for irrigation development. As a result, the Tono and Vea dams were constructed to enhance the status of these areas as food baskets in the regional context (Gordon, 2006). The region has an annual average rainfall of $921 \mathrm{~mm}$. It ranges between $645 \mathrm{~mm}$ and $1250 \mathrm{~mm}$. (GSS, 2012). The Region is predominantly agricultural with about 70 percent of the economically active population engaged in livestock rearing, farming or fishing (GSS, 2012). The Tono reservoir was constructed in 1975 but became operational in 1985 (Gordon, 2006) with a volume of $9.26 \times 10^{7} \mathrm{~m}^{3}$ (Gordon, 2006).

The choice of the mechanization centers and the concentration of the research work at TONO and VEA irrigation project sites was due to the fact that, these areas formed the Agriculture and food economic zone in the region. There is an all year round farming activity at the irrigation sites which gave the researcher a fair assessment and the impact of mechanized farming on rural livelihood and food security situation of the people.

\section{Research Design}

For the descriptive survey qualitative and quantitative research methodologies were used to collect, interpret, and analyze data because according to Knupfer and McLellan (2001), Descriptive survey design allows for greater degree of accuracy, reliability, standardizations of measurement and the uniqueness of the study;much information can be obtained from individual respondents of the population.

One major weakness of descriptive research is that answers do not automatically give the explanation why people feel or think or behave in a certain way, why programs pose certain characteristics, why a particular strategy is used at a certain time and so forth.

The study used Structured Close-ended Questionnaires as the main instrument to collect data alongside with focused group discussions, key informant interviews and observation. These methods sought to provide an opportunity to have an in-depth knowledge of the research which hitherto was not clear. The non-stagnant nature of them ethod helped to modify the questions to suite the purpose of the interviews. Empirical verification was done via observation on attitudes and behaviours of farmers in the study area.

\section{Sources of Data}

Both primary and secondary data were used.Primary data were obtained from administered questionnaires and informal interviews with the various selected Mechanization centers and other stakeholders involved in the study. Secondary data were obtained from various sources of literaturesuch as journals, relevant Textbooks, conference papers, etc. 


\section{Sampling Procedure}

In all, Ten (10) Farm Mechanization Centers were purposively sampled across all thirteen (13) districts in the Upper East Region. In addition to that, Hundred (100) smallholder farmers were also selected for the sample frame. In order to meet the objective of ensuring a uniform spatial coverage of all the selected Communities, Bolgatanga, Navrongo and Fumbisi were sampled from across the Upper East Region. Tractor owners, smallholder farmers, operators and management of Mechanization Centers were the appropriate people who were interviewed. This is because of their adequate knowledge and information about the topic. This strategy was adopted to get access to some key informant in the communities.

A total of Twenty (22) Respondents were selected in Bolgatanga. This included, Two (2) Mechanization centres (i.e, ICOUR- VEA and Ministry of Food and Agriculture) and Twenty (20) smallholder farmers and Tractor owners. At Navrongo, a Total of thirty (31) respondents were also sampled. This included, One (1) Mechanization Centre (ICOUR -TONO) and Thirty (30) Tractor Owners and smallholder Farmers. In Fumbisi, fifty (50) tractor owners and smallholder Farmers and Seven (7) Mechanization centres were identified and sampled for the study. The choice of the mechanizations centres and the concentration of the research work at TONO and VEA irrigation project sites was due to the fact that, these areas formed the Agriculture and food economic zones in the region. There is an all year round farming activities at the irrigation sites which gave the researcher a fair assessment and the impact of mechanized farming on rural livelihood and food security situation of the people.

\section{Data Analysis}

Data collected was analyzed using descriptive statistics from SPSS and Microsoft excel. The results were presented in the form of Table, Charts, Pie- charts and Distribution table among others.

\section{Results and Discussion}

\section{Background Information}

As shown in Table 1, 72.55\% of the total samples were male whilst the female respondents constituted $27.45 \%$. This presupposes that more males go into agriculture production as compared to females in the study communities. The study also revealed that the number of people who go into farming decreases with age. This is evidenced in Table 1 where $36.89 \%$ of the respondents were between the ages of 30-39, whereas individuals who were between the ages of $40-49$ constituted $24.27 \%$ of the total sample. According to the results, the study was fairly represented by all levels of education. For instance, $29.13 \%$ of the respondents had no formal education and was involved in the agriculture production, $22.33 \%$ had basic education, and $25.24 \%$ had obtained a secondary education as at the time of the study whilst $23.30 \%$ had either partially or fully completed tertiary education. The evidence of the youth being involved in farming activities suggests that there may be single couples who were also actively involved in the production of agricultural produce. The demographic characteristics of the study revealed that $43.56 \%$ of the respondents were married whilst $36.63 \%$ were single at the time of the study. Whilst $14.85 \%$ were widows/widowers, $4.95 \%$ had divorced.

The results indicate that the average number of people in each household was about 6 people as shown in the histogram above. The normal curve as fitted on the histogram shows that the household size variable is nearly normally distributed. However, the data was widely dispersed from one household to another $(\square=$ 5.8).

\section{Mechanization Centers and its Accessibility to Farmers}

With respect to the existence of a mechanized center in the study communities, $84.49 \%$ of the respondents answered in the affirmative whilst $15.53 \%$ indicated otherwise. However, the average number of mechanized centers as disclosed by the respondents was about 32.3 in the study districts. This included one man smallholder Tractor operator mechanization centers, Government mechanization centers and mechanization centers belonging to companies.

The predominant type of machinery as used by farmers in the study districts was the tractor and implements. This was evidenced by $89.9 \%$ of the respondents. The other major farm machinery used by most farmers were the animal draught power $(60.61 \%)$ and the water pump $(49.49 \%)$.

As was discovered in Table 2 above, the tractor was the most used farm machinery and according to $91.18 \%$ of the respondents, they used the tractor mainly for farm 
operations. A follow-up question demanding to know what specific farm operations that the above mentioned farm machinery was used by the farmer during the planting and harvesting seasons revealed that ploughing and transportation of farm produce was the main purpose for the use of the tractor.

As to why they preferred this machinery for the chosen farm operation, the respondents indicated that the tractor was fast and could plough a vast land for farming than does the traditional hoe. Besides the smooth penetration of air into the soil and time saving, others indicated that the tractor makes the soil lose thereby facilitating smooth germination of the seeds.

The results revealed that $50.49 \%$ of the farmers in the communities seldom had access to the mechanized centres whilst $23.30 \%$ occasionally used the centers for agricultural activities. Though there was evidence that most people had knowledge of the existence of the mechanized centres, majority of them had no access to the mechanized centres for agricultural purposes. There is therefore the need to make accessible these mechanized centres for the intended use. The inaccessibility could be a reason of affordability if the mechanized centres are not offered free of charge to the farmers.

According to Table 5, majority of the farmers (92.16\%) indicated they had access only to a rented/hired tractor whereas $3.92 \%$ of the respondents revealed that they owned the tractor. However, $2.94 \%$ disclosed that they had access to a tractor that belonged to a family member.

\section{Source of capital for Agriculture business}

It is obvious that capital is a driven force for farmers in the Agriculture business. With regards to the source of funding for their cultivation, $73.47 \%$ of the farmers disclosed that they financed the agribusiness from their own generated capital. This is a major initiative that was taken by the farmers. However, the other farmers who could not finance their farming activities by themselves resorted to bank loans (19.39\%), help from family $(6.12 \%)$ and friends $(1.02 \%)$.

\section{The Support Mechanization Centers Give to Rural Livelihood Development}

There is no doubt that farm-power technologies other than a hoe offer considerable advantages in terms of area cultivated, total yields achieved, levels of drudgery, opportunities to redeploy family labour, and household food security. Households relying on family labour for all their farming needs survive at the margin of subsistence. Many do not even have sufficient essential hand tools for all household members and they are extremely vulnerable to the loss of key household members. Their lives are a continual struggle and they race against time from the initial preparation of their land for planting through to harvest and the untimely sale of produce to raise essential cash. The timeliness of their operations is often compromised by the need to hire out their labour to others at the busiest times of the year. Households headed by women tend to be overrepresented among this group, partly as a result of the loss of assets typically associated with widowhood and they are often among the poorest in a community. The motivation to mechanize is primarily driven by a wish to increase a family's food security, increase household income, or improve the quality of life. There are significant economic and social benefits to be derived from farm-power mechanization. These are economic and social. Economic benefit refers to increasing the efficiency of labour, reducing costs, increasing the area cultivated, undertaking more timely production, improving the quality of cultivation, increasing yields, adopting new crops, reducing harvest and post-harvest losses and earning a rental income through hiring farmpower services to others. Social benefit refers to reducing drudgery and workloads (particularly for women), improving safety and gaining prestige. The other benefit is encouraging younger and more innovative people to remain in rural areas and work on the land. This, in the long run, helps to facilitate a rapid livelihood development of the people especially, smallholder farmers in the rural communities in the region.

\section{Farm Size}

Figure 3 shows the number of acres of farm lands that were used by farmers during the farming season. The results showed a skewed distribution with a mean of 6 acres of land for the farming purposes.

\section{Number of acres and cost of ploughing}

The results in Table 7 reveals that the average number of acres of land as indicated by the respondents was 5.71 with a standard deviation of 5.53. This shows a wide variation of the number of acres ploughed by the farmers. The cost as disclosed by the respondents stood approximately at $\mathrm{GH} \phi 90.81$ per hectare. According to the respondents it takes approximately 8 days for a 
complete preparation of the land for planting. The opinion of farmers on mechanization and farm size revealed that the use of mechanization would help them to expand the size of their current plantation. The expansion of the farm size implies more crops being planted and as a result, production is increased.

\section{Mechanization on poverty reduction}

According to Table 8,87.88\% of the respondents agreed that mechanization could help reduce poverty in these Districts. Mechanization of agriculture production, according to the respondents, creates more employment for the people in the rural communities. This, they say, will help them to expand on their current level of production thereby increasing the incomes of each farmer. Besides the reduction of poverty, the respondents added that food security in the communities would be ensured with the use of mechanized agriculture production.

\section{Mechanization and Its Effects on Rural Livelihood}

With respect how mechanization could affect the cultivation of traditional staples, $79.80 \%$ of the farmers indicated that it is not entirely the case. Hence, the cultivation of traditional staple foods cannot be tied to mechanization.

\section{Description of the Study Area}

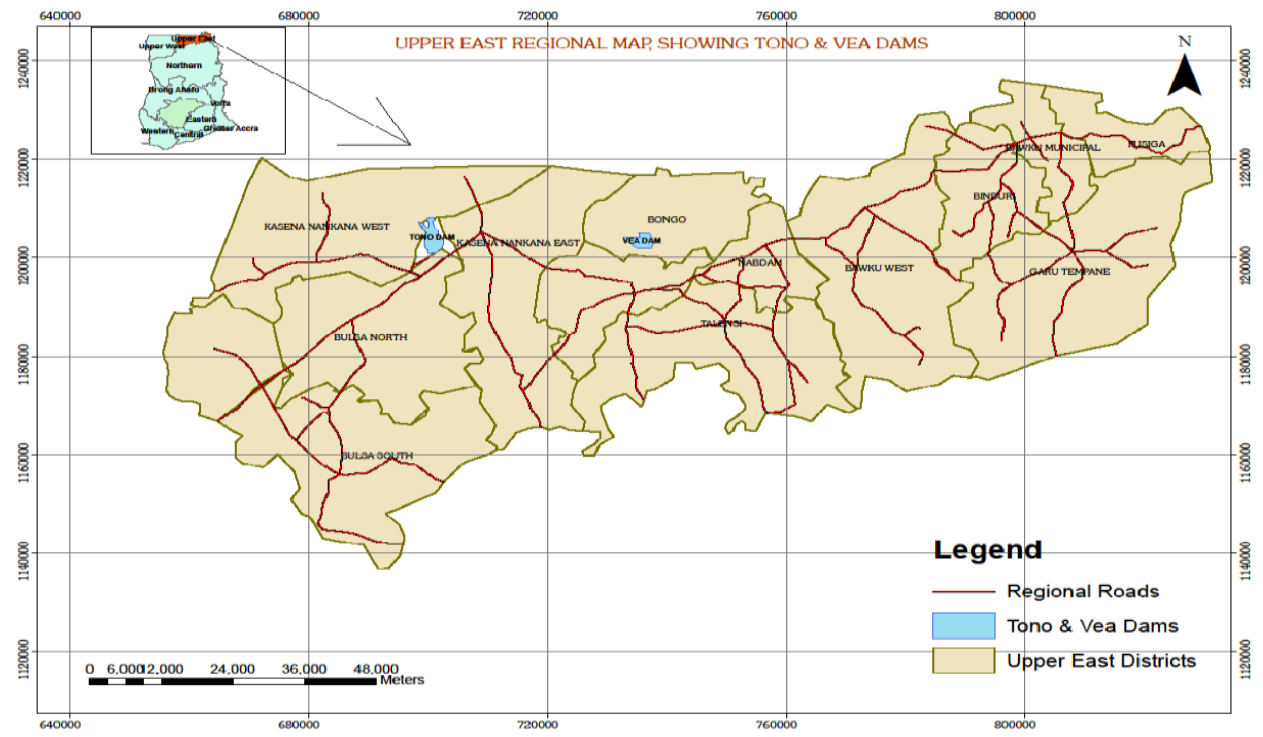

Fig.1 Distribution of household size

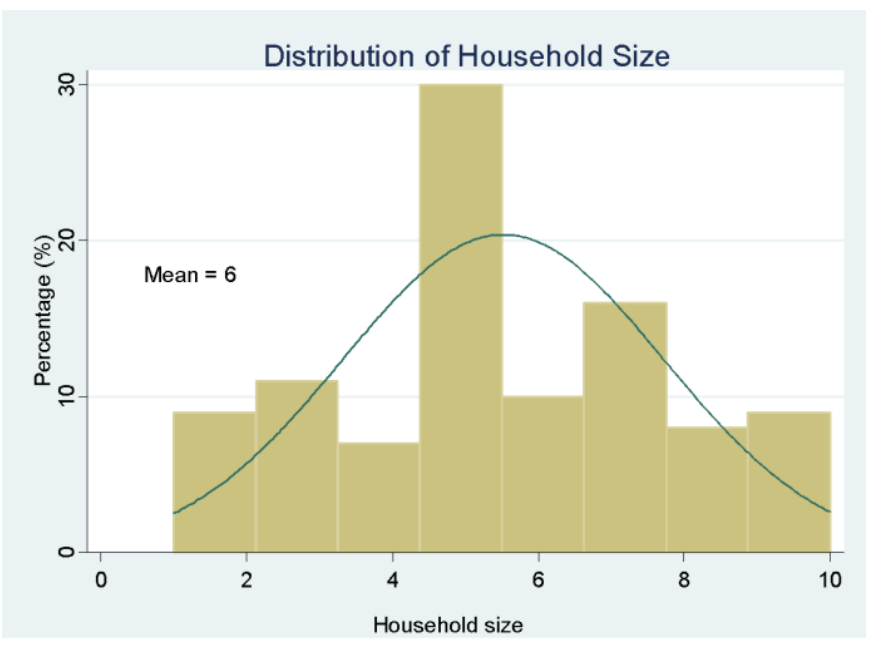

Source: (Fieldwork, 2017) 
Fig.2 Type of farm machinery

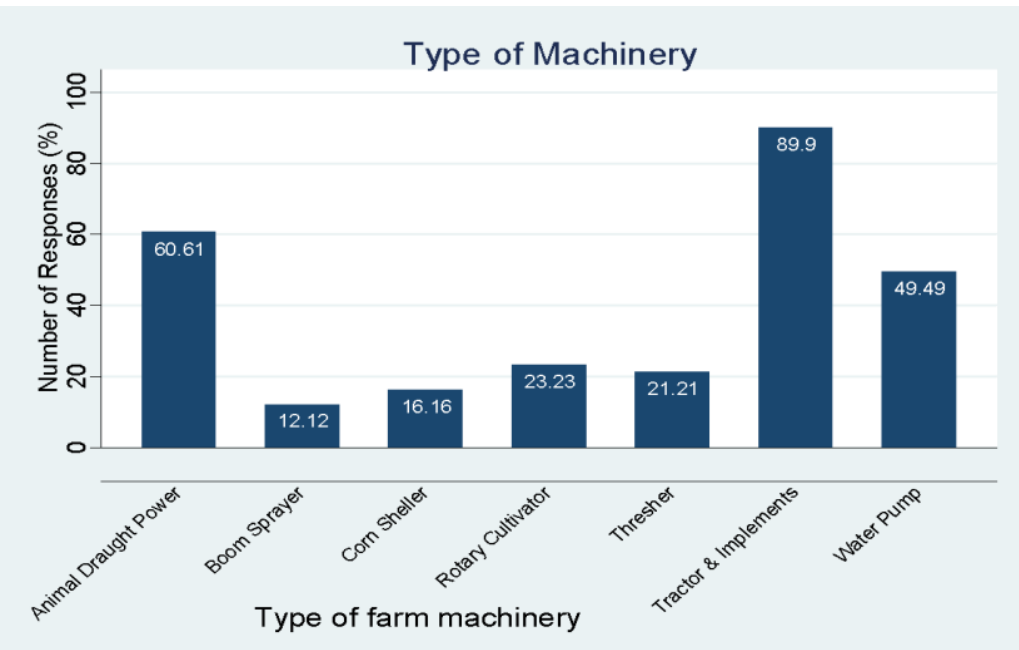

Source: (Fieldwork, 2017)

Fig.3 Farm size

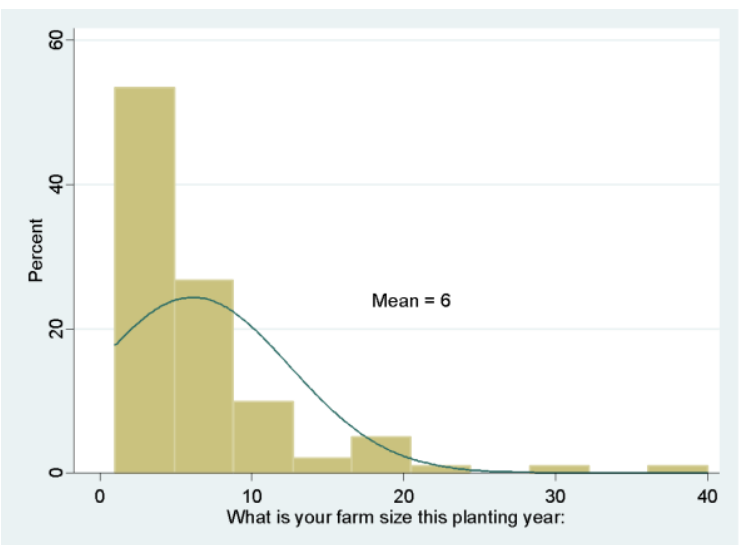

Source: (Fieldwork, 2017)

Fig.4 Maintenance Schedules

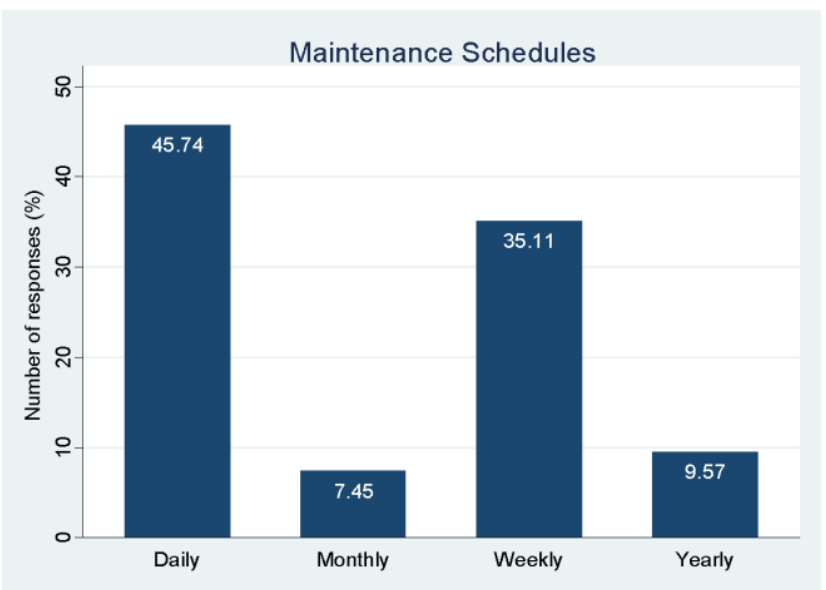

Source: (Fieldwork, 2017) 
Below shows the breakdown of the sampled Districts for the study

\begin{tabular}{|l|l|l|}
\hline NO & District & Sampled Respondent \\
\hline 1 & Bolgatanga & 22 \\
\hline 2 & Navrongo & 31 \\
\hline 3 & Fumbisi & 57 \\
\hline 4 & Total & 110 \\
\hline
\end{tabular}

Table.1 Demographic Characteristics of respondents

\begin{tabular}{lll}
\hline & Number of responses & Percentage (\%) \\
\hline $\begin{array}{l}\text { Sex distribution } \\
\text { Male }\end{array}$ & 74 & 72.55 \\
$\begin{array}{l}\text { Female } \\
\text { Age distribution }\end{array}$ & 28 & 27.45 \\
$20-29$ & & \\
$30-39$ & 29 & 28.16 \\
$40-49$ & 38 & 36.89 \\
$50+$ & 25 & 24.27 \\
Level of Education & 11 & 10.68 \\
No Education & 30 & \\
Basic & 23 & 29.13 \\
Secondary & 26 & 22.33 \\
Tertiary & 24 & 25.24 \\
Marital Status & & 23.30 \\
Married & 44 & \\
Single & 37 & 43.56 \\
Widow & 15 & 36.63 \\
Divorced & 5 & 14.85 \\
\hline & Source :(Fieldwork, 2017)
\end{tabular}

Table.2 Existence and average number of mechanized centers

\begin{tabular}{lll}
\hline & Number of responses & Percentage $(\boldsymbol{\%})$ \\
\hline No & 16 & 15.53 \\
Yes & 87 & 84.49 \\
Total & 103 & 100.0 \\
\hline \multicolumn{2}{r}{ Source :(Fieldwork, 2017$)$}
\end{tabular}

Table.3 Use of tractor in farm operations

\begin{tabular}{lll}
\hline & Number of responses & Percentage $(\boldsymbol{\%})$ \\
\hline No & 9 & 8.82 \\
Yes & 93 & 91.18 \\
Total & 102 & 100.0 \\
\hline
\end{tabular}

Source :(Fieldwork, 2017)

Table.4 Accessibility to mechanization centers

\begin{tabular}{lll}
\hline & Number of responses & Percentage $(\boldsymbol{\%})$ \\
\hline Frequently & 8 & 7.77 \\
Regularly & 18 & 17.48 \\
Occasionally & 24 & 23.30 \\
Seldom & 52 & 50.49 \\
Others & 1 & 0.97 \\
Total & 103 & 100.0 \\
\hline
\end{tabular}


Table.5 Accessibility of Tractors Services

\begin{tabular}{lll}
\hline & Number of responses & Percentage (\%) \\
\hline Hiring or renting & 94 & 92.16 \\
Personal tractor & 4 & 3.92 \\
Family member & 3 & 2.94 \\
Others & 1 & 0.98 \\
Total & 102 & 100.0 \\
\hline
\end{tabular}

Source :(Fieldwork, 2017)

Table.6 Source of capital for Agriculture business

\begin{tabular}{lll}
\hline & Number of responses & Percentage (\%) \\
\hline Banks & 19 & 19.39 \\
Friends & 1 & 1.02 \\
Family & 6 & 6.12 \\
Self & 72 & 73.47 \\
Total & 98 & 100.0 \\
\hline \multicolumn{2}{r}{ Source :(Fieldwork, 2017) }
\end{tabular}

Table.7 Number of acres and cost of ploughing

\begin{tabular}{lll}
\hline & Mean & Standard deviation \\
\hline Acres of land ploughed & 5.71 & 5.53 \\
Cost of ploughing per hector & 90.81 & 76.48 \\
Duration of land preparation & 8.32 & 11.37 \\
\hline
\end{tabular}

Source :(Fieldwork, 2017)

Table.8 Mechanization and poverty reduction

\begin{tabular}{lll}
\hline & Number of responses & Percentage (\%) \\
\hline No & 12 & 12.12 \\
Yes & 87 & 87.88 \\
Total & 99 & 100.0 \\
\hline
\end{tabular}

Source :(Fieldwork, 2017)

Table.9 Can mechanization affect cultivation of traditional staples?

\begin{tabular}{lll}
\hline & Number of responses & Percentage (\%) \\
\hline No & 79 & 79.80 \\
Yes & 20 & 20.20 \\
Total & 99 & 100.0 \\
\hline
\end{tabular}

Source :(Fieldwork, 2017) 
Table.10 Socio-Economic and Cultural Practices in Rural Livelihoods

\begin{tabular}{|c|c|c|c|c|c|c|}
\hline & $\begin{array}{l}\text { Strongly disagree } \\
(\%)\end{array}$ & $\begin{array}{l}\text { Disagree } \\
(\%)\end{array}$ & $\begin{array}{l}\text { Not } \\
(\%)\end{array}$ & sure & $\begin{array}{l}\text { Agree } \\
(\%)\end{array}$ & $\begin{array}{l}\text { Strongly agree } \\
(\%)\end{array}$ \\
\hline $\begin{array}{l}\text { Decision making in the } \\
\text { household }\end{array}$ & 7.07 & 17.17 & 34.34 & & 38.38 & 3.03 \\
\hline Widowhood rites & 17.35 & 31.63 & 7.14 & & 32.65 & 11.22 \\
\hline $\begin{array}{l}\text { Subordinate roles played by } \\
\text { women }\end{array}$ & 15.31 & 22.45 & 11.22 & & 41.84 & 9.18 \\
\hline Access to education & 5.05 & 11.11 & 4.04 & & 51.52 & 28.28 \\
\hline Access to health care & 7.07 & 6.06 & 8.08 & & 51.52 & 27.27 \\
\hline Access to credit facility & 31.31 & 9.09 & 7.07 & & 24.24 & 28.28 \\
\hline Access to land & 7.29 & 10.42 & 4.17 & & 44.79 & 33.33 \\
\hline Female household head & 14.74 & 21.05 & 11.58 & & 41.05 & 11.58 \\
\hline Insufficient purchasing power & 9.09 & 16.16 & 12.12 & & 46.46 & 16.16 \\
\hline $\begin{array}{l}\text { No recognition for women } \\
\text { roles }\end{array}$ & 7.07 & 16.16 & 9.09 & & 41.41 & 26.26 \\
\hline $\begin{array}{l}\text { Lack of data on alternative } \\
\text { sources }\end{array}$ & 9.09 & 18.18 & 11.11 & & 42.42 & 19.19 \\
\hline
\end{tabular}

Source :(Fieldwork, 2017)

Table.11 Smallholder farmers and Accessibility to Agriculture Support

\begin{tabular}{lll}
\hline & Number of responses & Percentage (\%) \\
\hline No & 18 & 17.82 \\
Yes & 83 & 82.18 \\
Total & 101 & 100.0 \\
\hline \multicolumn{2}{r}{ Source :(Fieldwork, 2017$)$}
\end{tabular}

Table.12 Type of agriculture support given to smallholder farmers

\begin{tabular}{lll}
\hline & Number of responses & Percentage (\%) \\
\hline Extensive service & 65 & 80.25 \\
\hline New technology & 20 & 24.69 \\
\hline Credit facility & 5 & 6.17 \\
\hline Acquisition of land & 1 & 1.23 \\
\hline Farm inputs & 21 & 25.93 \\
\hline
\end{tabular}

Source :(Fieldwork, 2017)

Table.13 How often do households receive Agriculture support?

\begin{tabular}{lll}
\hline & Number of responses & Percentage (\%) \\
\hline Frequently & 2 & 2.20 \\
Regularly & 5 & 5.49 \\
Occasionally & 33 & 36.26 \\
Seldom & 51 & 56.04 \\
Total & 91 & 100.0 \\
\hline & Source :(Fieldwork, 2017)
\end{tabular}


Table.14 Are current crop types different from previous crops?

\begin{tabular}{lll}
\hline & Number of responses & Percentage (\%) \\
\hline No & 85 & 83.33 \\
Yes & 17 & 16.67 \\
Total & 102 & 100.0 \\
\hline \multicolumn{2}{r}{ Source :(Fieldwork, 2017) }
\end{tabular}

\section{The Effect of Mechanization on Demand of Agriculture Produce}

The focus group discussions, according to the respondents, revealed a number of areas where mechanization has affected the demand of agriculture products in the area. It was disclosed that mechanization has brought about competition among the farmers in terms of crop production, helps to fight soil erosion as compared to previous farming season, land degradation, and effectiveness of land preparations. Others were of the view that mechanization has contributed tremendously in terms of high supply of food. This is due to the fact that mass agricultural production is encouraged which eventually increases production. With respect to areas where mechanization has contributed to the livelihood of the people in the study area, the respondents unanimously agreed that employment is one of the major achievements that mechanization has brought to the community. With increased transportation of farm produce, farmers are now able to cultivate in large quantities and transport same to the market. This has helped a great deal in reducing the poverty level of people in the Region.

In addition, farmers are now able to cultivate crops all year round with the help of the irrigation system. This is much better than the one season plantation within the year that most part of the region is still undergoing only during the raining season.

\section{Socio-Economic and Cultural Practices in Rural Livelihoods}

Table 10: presents rating of the socio-economic and cultural practices in the community that affects the livelihood of the people. It was observed that there was high level of agreement among several items as affecting the livelihood of people in the community. Notable among them were access to education and health care needs. Access to land and issue of female household heads were also recognized as some of the factors that adversely affect the livelihood of people in the study communities. Besides the lack of data on alternative livelihoods sources, insufficient purchasing power of farmers, the failure to recognize the roles women play in the farming industry, were also seen as a danger zone as far as the livelihood of people in the community is concern, other respondents were of the view that access to credit facility and the subordinate roles played by women within the households were not serious challenges that could affect the livelihood of people in the community.

\section{Type of Agriculture Support Given to Smallholder Farmers}

There was enough evidence from the respondents to suggest that smallholder farmers had access to agriculture support as indicated in Table 11. The areas that serve as evidence of the support as was disclosed by the respondents is presented in the next section.

The results suggests that smallholder farmers had massive support for their agriculture business in the areas of extensive service $(80.25 \%)$, new farming technology (24.69) and farm inputs (25.93\%). Credit facilities and land acquisition were not emphasized much probably due to the fact that most of the farmers had their own finances or capital for the cultivation.

Though there was an agriculture support system, respondents indicated that they did receive such support. About $36.26 \%$ said they received such support occasionally. It also revealed that, $56.04 \%$ seldom got support. Whereas, just about $5.49 \%$ were supported on regular basis. In all, there is clear indication that, the supply of agriculture supportive resources to farmers in the study area is irregular.

\section{Major Crops Cultivated}

The major crops cultivated as indicated by the respondents are: maize, millet, beans, soybeans, groundnuts, rice, tomatoes, cowpea and sorghum in the study area. 
The change in crop pattern since the Inception of Mechanization Centers

During the current government, agricultural sector has got better attention and emphasis. The sector has got are cognition that the overall economic growth in the country depends on the performance of this sector. Accordingly, a number of agricultural development strategies and plans have been formulated and implemented. As the major contribution of agriculture comes from smallholder farmers, the government put a clear agricultural development strategy focusing on enhancing technology generation and use by smallholder farmers to close the productivity gap in major crops. However, smallholder agricultural mechanization has not got equal attention to other yield improving inputs/technologies like improved seeds and fertilizers.

\section{The State of Current Crops from the Previous Years}

At the focus group discussion, it was revealed that differences in crop yield increase in the sizes of their farm lands and agriculture arable area in the districts of the region has contributed significantly in large farming activities. Farm machinery, the use of new technologies in agriculture mechanization was another reason for the increase in food production in the Region according to the people in the study area. The fertilizer subsidy programme instituted by Government and the Ministry of Food and Agriculture (MOFA) in recent years has also played a major role in this achievement.

\section{Challenges Faced By Tractor Owners}

Tractor, like any other equipment, has its own challenges that could hinder the smooth operation. The discussions with major stakeholders in the farming industry revealed a number of issues that seriously affect tractor owners from smoothly running their farm operations. The result indicates that bad road network from the rural to the urban communities served as the major challenge as faced by tractor operators. This makes it difficult for them to move into the farm lands any time there is a heavy downpour of rain. The cost associated to the operations of a tractor such as cost of production, fuel and maintenance of the tractor were also concerns raised by the respondents. Besides the low demand in the market, lack of qualified or skilled operators makes it difficult for the smooth running of the tractors as the operators are not able to use the machines appropriately. Also, site selection, land acquisition and inadequate capital were not left out. With the increasing growth of green grass in the rainy season, snake bites during cultivation cannot be overlooked as some of the respondents re-echoed.

\section{Routine maintenance schedules used for farm machinery}

A good maintenance culture preserves the live of the farm implements. It was observed from the study that farmers mostly schedule for maintenance of farm machinery on daily basis $(45.74 \%)$ as evidenced in Figure 4. Some of the farmers also indicated that they do service or schedule for maintenance on a weekly basis (35.11\%). However, a few farmers ignore the regular maintenance schedules and either service at the end of the month or annually.

The main objective of this study is to assess the impact of mechanization on agricultural production in rural livelihood in Bolgatanga Municipality, Navrongo and Fumbisi Districts and how it impacts agricultural land use. Smallholder farmers need farm power and mechanization to raise the productivity of their land and labour to see improvements in farmer's family livelihoods. This essential input is not only needed for agricultural production but along the value chain for farm produce. Mechanization is needed to alleviate drudgery and to alleviate the load on women, children and the elderly, all of which equates to an increase in labour productivity. The provision of mechanization centers as part of the modernization of agriculture has played and continues to play important roles in poverty reduction and boost productivity in the Upper East Region in particular. The study shows a positive relationship between tractor use and farm size expansion among smallholder farmers in the Upper East Region of Ghana. Findings show that farm size expansion over the one-decade occurred among majority of respondent smallholder farmers irrespective of landholding size. Notwithstanding the contributory role of other factors that enhanced their ability to expand, especially the availability of demand for farm produce, all respondent farmers noted that tractor use was the primary catalyst that aided the expansion of their farms. Respondent smallholder farmers outlined the advantages tractors offered over the previous use of manual means and animal plough in land preparation to include the ability to plough larger areas faster and better even with the least rainfall and the ability to control weeds effectively. Closely related to the expansion in farmlands among smallholder farmers is an emerged pattern of farm location in where relatively smaller farms are clustered 
around bigger ones. The findings further reveal that, the clustering is attributed to the fact that locating farms close to each other has the higher potential to attract tractor owners who prefer zones with enough farms they can plough to meet a daily quota. Also, in view of the fact that smallholder farmers with relatively bigger farms are some of those who own personal tractors, others with relatively smaller farms locate their farms close by in order to get timely tractor access. The evidence from the findings of the study was that mechanization centers contribute towards poverty reduction in the rural livelihood.

\section{Recommendations}

Based on the findings and the conclusion the researcher makes these recommendations. The benefits and gains of Mechanization Centers are not many and only limited to a number of farmers and some of the Mechanization Centers have collapsed, communities have no access and control of such resource. Therefore government agencies, institutions, and departments and Nongovernmental Organizations, civil society (e.g. Community Based Organizations) individual benevolent and philanthropic organizations who also redirect more of their resources in promoting mechanization centers among Districts within the Upper East Region in order to reduce their vulnerability levels resulting from farming failures. Improving smallholders' access to farm power and machinery inputs is crucial as machinery purchase is often beyond the means of a large proportion of the sector. Group ownership is a possibility and can be supported by public sector incentives. Private sector custom mechanization services are probably the most appropriate vehicle and should be supported by public sector incentives and training. Mechanization centers have some kind of challenges and the implication is that they lack skills personnel, bad road network to farm lands, site selection and land acquisition. NGOs initiatives and (MOFA) externally to mediate timely access to tractors for land preparation, enough land and obtain credit to finance tractor services. Therefore, marketing systems and structures should be established and developed to enhance the marketing of agricultural produce especially for rural communities. There is a wide range of appropriate mechanization options suited to smallholder farming conditions. The important point is to make the options available by involving all stakeholders in the mechanization input chain. This means, including farmers, manufacturers, dealers, and academia and policy makers. The private sector must be the main supplier of mechanization inputs to ensure sustainability of supply and service into the future. This should include value chain linkages, road infrastructural development and other transport requirements, Therefore, MOFA, research institutions and the private sector should collaborate to develop and sustain value chain systems for farm machines in the region.

\section{References}

Amanor, K. S., and Pabi, O.(2007). Space,Time, Rhetoric and Agricultural Change in the Transition Zone of Ghana. Human Ecology, 35(1), 51-67

Andah, W.E.I., Van de Giesen, N., Biney, C.A. (2003). Water, Climate, Food, and Environment in the Volta Basin, Contributions to the project ADAPT. Adaptation strategies to changing environments

Asuming-Brempong, Samuel, Ramatu Al-Hassan, Daniel Bruce Sarpong, George T-M. Kwadzo, Sesi K. K. Akoena, OwurakuSakyi-Dawson, Akwasi MensahBonsu, Ditchfield P.K. Amegashie, Irene Egyir and Steve Ashley. 2004. Poverty and Social Impact Analysis (PSIA) Studies for Ghana: Economic Transformation of the Agricultural Sector. Final Report submitted to the National Development Planning Commission (NDPC)/ Ministry of Food and Agriculture (MoFA), and DFID, Ghana, for the "Economic Transformation of the Agriculture" Sector Study. Report submitted in June 2004 by the Department of Agricultural Economics \& Agribusiness, University of Ghana and Department of Economics, University of Ghana with technical support from The IDL Group, U.K

Chamberlin Jordan (2007), Defining Smallholder Agriculture In Ghana: Who Are Smallholders, What Do They Do and How Are They Linked With Markets? Ghana Strategy Support Program (GSSP) Background Paper No. GSSP 0006 www.ifpri.org August 2011(retrieved)

Coulombe and Mckay \{2003\} Poverty Trends in Ghana in the 1990s. Ghana Statistical Service, Accra, Ghana

Ghana Poverty Reduction Strategy (GPRS) 2003-2005. An Agenda for Growth and Prosperity, Accra: Ghana.

Ghana Statistical Service (2012). 2010 Population and Housing Census. Final Results. Accessed online on 20th April, 2015 at 110

Ghana Statistical Service, (2000) Ghana livings Standard Survey: Report of the Fourth Round. Ghana Statistical Service Accra. 
Ghana Statistical Service, (2008) Ghana livings Standard Survey: Report of the Fifth Round. Ghana Statistical Service Accra

ISODEC, (2005) Social Accountability and Poverty Reduction in Ghana; Community Assessment of Five Districts, CBA Accra

Kassena- Nankana D istrict Assembly \{1991\} Profile of the Kassena-Nankana District. Navrongo, Ghana. \{Unpublished\}.

\section{How to cite this article:}

Maurice Mustapha. Braimah, Bright Buzong Yintii and Avomah Oscar Mac Akampirige. 2017. Assessing the Impact of Agricultural Mechanization Centers on Agriculture Production and Rural Livelihoods in the Upper East Region, Ghana. Int.J.Curr.Res.Aca.Rev. 5(8), 112-125.

doi: https://doi.org/10.20546/ijcrar.2017.508.016
MOFEP, (2008), 2008 Budget of Ghana. www.ghana.gov.gh or www.mofep.gov.gh (12/2/09)

Todaro P.M. and Smith S. (2009) Econnomic development in the third world. Tenth Edition. Pearson Education Limited, England

Uphoff, N. $\{1985\}$ "Fitting Projects to People" in M. Cernea \{ed $\}$ Putting People First; Sociological Variables in Rural Development. Oxford University Press, UK. 